\title{
Press-State Relations: A Comparative Analysis of Euro-Mediterranean and British Models ${ }^{1}$
}

\author{
*Raúl Magallón Rosa, Josep M Sanmartí Roset, Guadalupe Aguado Guadalupe \\ Department of J ournalism and M edia Studies, Carlos III University of M adrid, Spain. \\ *Correspondence to: Raúl Magallón Rosa, raul.magallon@uc3m.es
}

Published online: January, 2010

\begin{abstract}
The objective of this article is to compare the State's role in the progress and development of the press system in relation to the Euro-M editerranean model and that of English-speaking countries. Within this framework, we will discuss historic moments that may be considered decisive in the configuration of both systems today, and that have influenced how they came about. Additionally, we will examine legislative measures that have been most noteworthy in the progress of the press market in recent years. The State's influence on the transformation of the newspaper business is studied from the following perspectives: censorship, control systems, regulation of the figure of the journalist, aid to the press, pluralism of information and limits on concentration. These aspects were selected because they have been observed to be key points to understanding Press-State relations. In the four EuroMediterranean countries studied, a radical break took place in the information systems as a consequence of the implementation of their respective totalitarian regimes between 1926 and 1976; a situation which did not occur in Great Britain, a major figure of democratic and business continuity. Whereas the disappearance of aid to the press in the British model was understood to be a means of guaranteeing the independence of the journalism profession from those in political power, in the Euro-Mediterranean model the aim of aid for press distribution is to consolidate the cooperative distribution system, preserve the pluralism of newspapers reporting political and general news, and guarantee the development necessary for the effective exercise of liberty proclaimed in the Declaration of the Rights of Man and the Citizen 1789.
\end{abstract}

Keywords: Press; State; Control; Censorship; Euro-M editerranean; British.

\section{Introduction}

The objective of this article is to analyse the State's role in the progress and development of the press in certain European countries. On the one hand, we have examined the Euro-Mediterranean bloc (Spain, France, Italy and Portugal) countries, which all have a decidedly regulatory attitude on the part of the State. On the other hand, we have looked at the English-speaking bloc, centred fundamentally on the United Kingdom, which is characterised by the inhibition of public powers, developed in concordance with the North American tradition begun with the First Amendment to the U.S. Constitution (December 15, 1791). This First Amendment states "Congress shall make no law respecting an establishment of religion, or prohibiting the free exercise thereof; or abridging the freedom of speech, or of the press; or the right of the people peaceably to assemble, and to petition the Government for a redress of grievances".

The common starting point of the Euro-M editerranean model is found in the Declaration of the Rights of Man and the Citizen of August 26, 1789, enacted at the outset of the French Revolution. Its article 11 maintains that "The free communication of thoughts and of opinions is one of the most precious rights of man: any citizen thus may speak, write, print freely, save [if it is necessary] to respond to the abuse of this liberty, in the cases determined by the law".

\footnotetext{
${ }^{1}$ This research has been carried out at the Institut Français de Presse (Université Panthéon-Assas- Paris II), the Instituto de Estudos Jornalísticos de la Universidade de Coimbra (Portugal) and the Institute of Communication Studies (University of Leeds, United Kingdom).
}

http://astonjournals.com/assj 
Hence, the Declaration established a categorical mandate to ensure and regulate by law the right to freedom of information, and this principle has always prevailed at the heart of the diverse regulatory measures in these countries. The Declaration of the Rights of $\mathrm{M}$ an and the Citizen considers freedom of print as a right which must be positively preserved and which may, at the same time, collide with other rights. As a result, the State is presented as the guarantor of both this public service and the free exercise of all other rights.

Additionally, in the four Euro-M editerranean countries analysed, a radical break in the information systems took place as a consequence of the implementation of their respective totalitarian regimes between 1926 and 1976, a situation which did not occur in Great Britain, a major figure of democratic and business continuity. The measures taken by the different States in accordance with their political regime decisively determined the path the press has taken up through the present day. This in turn enables us to understand the causes that have brought about diverse business strategies, successful to a greater or lesser extent depending on the case, and which have led to a specific business conglomerate with the consequent business systems of journalism in each country.

\section{The Practice of Censorship}

Censorship was present in the formative stages of the English press, but at the end of the 17th century, the right to freedom of expression was prevailing in laws and constitutional pacts. Throughout the 18th century, there was great tension between the application of this principle and everyday reality. Taxes and fees displaced means of coercion, although certain political actions, in practice, meant censorship. Then, at the end of the 19th century, the English model was freed of this limitation, except during the two World Wars and in certain specific matters, such as terrorism in Northern Ireland.

The practice of censorship was much longer and more permanent on the Continent because those in power generally held much more interventionist positions. Despite all that, the Euro-M editerranean countries reached the 20th century in a position of relative freedom of the press, which was swept away by the implementation of totalitarian regimes in all four. In the case of Portugal and Spain, this went on until 1974 and 1976 respectively. Its existence in such advanced times and its persistence was one of the essential elements in the emergence of this press model.

\section{The United Kingdom: No Censorship since the 19th Century}

Censorship was certainly one of the problems that the budding English press had to face throughout the 17th century, despite which several widely varied newspapers, aggressive within the framework of serious internal conflict, made their appearance. Under the reign of Charles I (1625-49), which was of absolutist tendencies, the press had to bear severe restrictions including in the granting of licenses. This lasted during the civil wars from 1640 to 1648, provoking an angry protest by John Milton in 1643. During Oliver Cromwell's Republican government (1649-58), limitations to the press continued. In spite his reign's Whig and Tory pact-making character, Charles II (1660-1685) had the Licensing Act (1662) approved, a very restrictive regulation that established prior censorship, authorised publication only by members of the Stationer's Company and reserved for the king the right to authorise or deny news publication. Thus, the Licensing Act, applied rigorously by James II (1685-88), gave rise to a model of intervened-on press quite similar to that of the French gazettes, with the "London Gazette" standing out.

A pact between William III of Orange and the anti-Stuart revolutionaries led to the Bill of Rights (1689), England's constitutional foundation, despite which the Licensing Act was observed until 1695. Nonetheless, after 1712 various restrictions were implemented particularly in terms of taxes, such as the Stamp Act of 1765 allowing for numerous episodes of interference in the running of newspapers, at which Whig M inister Robert Walpole distinguished him.

http://astonjournals.com/assj 
As Nieves Saldaña states, "in effect, the abolition of the English censorship system in 1695 turned seditious libel into the principal legal mechanism that the British crown had to restrict political criticism, becoming, as of the $18^{\text {th }}$ century, the paradigmatic vehicle for controlling public opinion on both sides of the Atlantic" [1].

It was in England that the Libel Act was approved in 1792. It was the first law of the bourgeois press, and repressive in practice as a reaction to the French Revolution and the rise of the popular press. In spite of everything, this law, reformed in 1843, already specified the accusations for which journalists could be taken before a jury. Moreover, in 1819 there was a significant reduction of mastheads because of the Six Acts, officially assigned to prevent terrorist attacks and in the process, persecute the most radical publications. At the end of the 19th century Common Law prevailed, which permanently transferred the prosecution of crimes of the press to ordinary justice.

In addition to certain censorship measures at the time of the two World Wars, "underground" censorship was evident mainly in relation to the conflict with the IRA in Northern Ireland during the second half of the 20th Century.

\section{Euro-Mediterranean Model: Limits to Freedom of Expression and Publication}

In the course of Portuguese history, its press market has been affected by censorship, which was instituted in 1926 because of a military coup, and which produced a corresponding loss of freedom of expression and publication. This situation lasted until the end of the Estado Novo dictatorial regime. After nearly five decades, censorship was abolished on April 25, 1974 when a coup d'état put an end to 48 years of dictatorship.

A similar situation took place in Spain, where the Civil War (1936-39) opened up a new era characterised by State intervention. In the new political-administrative system, a new press law played an essential role. All media was placed at the service of the State and it was entrusted with the mission of re-educating the citizens in its new values. Prior censorship, along with obligatory publication of slogans and information, was one of the tools used most intensely. At the same time, the National Press Service (SNP) set up strict control mechanisms from the naming of newspaper directors to an Official Registry of Journalists (ROP) who were authorised to practice the profession. In 1951 the Ministry of Information and Tourism was created to centralise all these supervisory functions.

The censorship system of 1938 ended with a limited process of liberation expressed in the Law of Press and Print of 1966, complemented by the Statute of Advertising of 1964, the creation of the National Union of Press, Radio, Television and Advertising of 1964, the Statute of Children's and Youth Publications of 1967 and the Statute of the Journalism Profession of 1967, among other regulatory texts. The new system for the press led the newspaper business to move from the domain of national interest to that of private initiative, and so slogans and prior censorship as a normal procedure were reserved solely for cases of national emergency or war. However, a Registry of Newspaper Companies (REP), containing all information on every publication and their administrative budgets, was required, and in accordance with the concept of information of general interest, the government could oblige any publication to insert, at no cost, notes from the General Directorate of the Press (DGP).

Furthermore, the law authorised the administrative seizure of publications and provided for sanctions for those who wrote or published anything considered to be against the Fundamental Principles of the Movement and the legal order of the Franco regime. It also set severe conditions for the naming of directors and maintained the Official Registry of Journalists (ROP), with all journalists holding a card issued by the Ministry authorised to practice their profession, as well as a Panel of Professional Ethics, which replaced the 1955 Tribunals of Honour. The Administration, therefore, reserved ample sanctioning power although it allowed journalists to appeal possible administrative sanctions through a judicial review procedure. Despite retaining a repressive nature, this law permitted the opening of a number of mastheads and opened up some areas of freedom of expression. In short, Spain had aligned itself amongst the totalitarian regimes, which were those that in the period between Wars began to execute regulation and control of the journalism profession as an instrument of control of the press [2].

http://astonjournals.com/assj 
In Italy, Law no. 374 of February 2, 1939 -which repealed the regulations of Law no. 654 of May 26, 1932- set the compulsory requirement to deposit eight copies of any printed publication before different institutions (one for the M inistry of Popular Culture, three for the Prefecture, one for the Crown Prosecution Service and three for the provincial delegation of the M inistry of Education). A point of this law, which stands out, is that this obligation also included any reprint that had been modified in either content or form.

Also specified was the requirement that any publication state in a clearly visible way the legal address of the printer and/or editor, in addition to the year according to the Christian calendar and to the Fascist calendar (article 5). After the fall of Mussolini on July 25, 1943 and the referendum of June 2, 1946, in which the Republic was founded, a new Constitution was adopted, going into effect on January 1, 1948 and whose article 21-guaranteed freedom of the press.

In France the freedom of the press law of 1881, in force today although reformed on several occasions, lifted the preventive measures in effect until then and reduced administrative measures prior to publication. Nevertheless, in the application of article 11 of the Declaration of the Rights of Man and the Citizen (1789), which established legal limits to this freedom in an effort to preserve it and protect the other freedoms, certain legal discretionary measures were established. Offenses to the President of the Republic, direct incitement to commit an offence or crime, disobedience of military commands, or acts committed against foreign institutions or sovereigns could be prosecuted. As a whole, it protected the right to criticise those in political and administrative power. The Correctional Tribunal was reserved solely for crimes of defamation against private persons; all others were transferred to the jurisdiction of the court (Cour d'Assisses). The preventive seizure of publications by administrative authorities was prohibited in 1889. The law was temporarily suspended in 1884 and 1893, due each time to an anarchist crisis.

Censorship returned in 1914 as a result of the First World War. A Press Office, attached to the Ministry of Defence, was created to revise all written material before publication, producing a great deal of friction between the newspapers and the military authorities. However, it made the war bearable for the civil population and was proven efficient at maintaining faith in victory [3]. The lifting of censorship in 1919 did not stem strong questioning of the law of 1881 due to the defamatory excesses it allowed, a fact that acted in the progressive discrediting of the III Republic. On August 28, 1939, censorship was re-established, although in a less strict form than in 1914. It was maintained on much tougher terms in the Vichy territory (1940-42) and in the Nazi-occupied areas, combined in the former by slogans and obligatory notes and culminating in total intervention. The decrees of May 6, June 22, August 26 and September 30, 1944 issued by the provisional government emerging from the Liberation, repealed censorship but set several administrative measures which at times had a similar impact.

The permanence of these administrative controls has been considered to be contrary to freedom of expression both in normal times and in exceptional ones. Thus, in the first case administrative authorities can even seize publications in order to preserve public order. The possibility of suspending constitutional guarantees during states of emergency, siege or war leave the possibility of re-establishing censorship open [4].

\section{Guidelines of the Two Models}

Once tensions stemming from the Civil War of the 17th century were resolved, Great Britain entered more deeply into a model characterised by relative freedom of expression, recognised in the Bill of Rights of 1689, but penalised through a network of tariffs and fees that blocked a pioneer mass press. In the mid 19th century, these taxes began to disappear, leaving the way open for a similar system to the one in North America with freedom of enterprise and of expression, and merely subject to common laws.

To the contrary, the Euro-Mediterranean legal system was under debate throughout the 19th and 20th centuries, in 
search of rules that fit together the principle of freedom of expression, also recognised in the respective Constitutions, with the intense political difficulties. With its pact-like character, the French law of 1881 was the one that brought both extremes closest together, serving as an example for the other countries of the bloc, such as Spain. The establishment of totalitarian regimes and the Second World War acted as a radical break in the press systems of the four countries with different outcomes for each of them.

\section{Great Britain's Model of Liberal - Continuation}

After the 17th century, which was periodically stormy but very active due to civil struggles, at nearly the end of the 18th century, business press appeared in Great Britain. Newspaper companies introduced technical innovations, created an informative infrastructure for newsgathering and improved distribution systems, especially with the first railways. Companies appeared that had a new perspective, and with the goal of making money, they modernised their businesses, reduced costs and increased their productive capacity. An example of all this was the newspaper The Times, founded in 1785 and a leader in the country from 1803.

In about 1830, the English press was a very active sector, directed primarily by the social elite. The political press targeting the middle classes was calmer than that on the Continent inasmuch as there was parliamentary stability with the liberals holding power for long stretches of time. In this atmosphere, the press as political loudspeaker and agitator played a less significant role than it did on the Continent, which was much more turbulent, and the stage for different revolutionary processes.

To the contrary, the workers' press showed itself to be logically more radical, given that the working sector was gaining class experience and improving its level of awareness and organisation. By 1824, George IV partially permitted Trade Unions, organisations halfway between the ancient guild structures and trade unionism. It is not surprising that, for example, in around $1850 \mathrm{Karl} \mathrm{M}$ arx was in London, writing for different newspapers to make a living. The repeal of tariffs in 1853 encouraged the growth of a cheap, competitive press, which was consequently popular, not counting local and regional newspapers.

The 20th century saw hegemony of the press in the United Kingdom because of a new generation of ownerbusinessmen. The most important of them all was Alfred Harmsworth, later Lord Northcliffe, who obtained control of the Daily Mail, the Daily Mirror, the Times and The Observer. Northcliffe's brother, Lord Rothermere, the Canadian businessperson M ax Aitken, later Lord Beaverbrook, and brothers James G. and William E. Berry, Viscounts of Kemsley and Camrose, came to dominate the British national and regional press. All the editors used their newspapers to strengthen their political objectives and ideas, driving the conservative prime minister Stanley Baldwin to call them to task for exercising power with no responsibility.

It is precisely its peculiar relationship with those in power that marked the future of the British press. Different from what has occurred in certain Euro-Mediterranean countries, and in contrast to France, which was even more politically centralised, the tradition in Great Britain of newspapers of a political character has been much weaker. Following the death throes of the Daily Herald, over the last forty years there has not been a newspaper that was formally of the Labour Party, nor has there been significant Communist press. There have been no subsidies, neither directly through political parties or affiliated individuals, nor indirectly from the State, which have supported political press, as in the rest of Europe [5]. In 1945 four conservative newspapers, two labour newspapers, two liberal newspapers (including the Manchester Guardian) and the communist Morning Star still came out [6]. That is why, between 1945 and 1995 the press was less and less predictable and manageable for the parties, and therefore less satisfactory for them [6].

For the press, the result was an increasing risk which frustrated politicians, who attempted to correctly or incorrectly blame the press for their failings [6]. To begin, there was an imbalance in the number of party newspapers. One of the principal causes is that the United Kingdom has neither written Constitution nor even a Freedom of Information Act, and 
only recently has incorporated the European Convention of Human Rights to its internal laws [7].

Together with a system that defends freedom of the press, another of the key factors of the English press has been the sector's industrialisation. Macu Álvarez points out that new technology applicable to the press reached the United Kingdom at the same time, as there was a chronic lack of profits. The journalism industry was characterised by an adverse cash flow, high production costs and low potential development due to market saturation and the effects of the economic recession. Hence, in 1977 a Royal Commission - the third since the Second World War- was set up in order to carry out an in-depth review of the journalism industry. The analysis was posed not as a matter of income, but of costs. Discussed was a more than $50 \%$ reduction in work force, affecting editorial departments. These reductions could spread to other production areas, achieving a 30\% savings in salaries. The analyses of the British newspaper industry, especially those of national scope, placed emphasis on the generosity of employment levels and the high salaries that had been applied to their workers. New technology became, therefore, a powerful tool, not only to reduce the volume of salaries but also to counteract the power of the unions. In this regard, remember the Wapping labour confrontation in 1986 and 1987, which arose when businessman Rupert Murdoch proposed taking his business away from the powerful Fleet Street typesetters union and abolishing outdated printing methods [8].

All this has resulted in a press model in which, ever since 1945 a clear distinction was drawn between quality press and popular press, a classification that continues to this day with a distinction between quality, middle market and popular papers. This classification is the configuration of one of the most important newspaper markets in the world. Every day nearly 19 million copies are sold for a total 58.8 million inhabitants, figures that place it as the sixth power in terms of volume of daily newspaper sales following China, Japan, the United States, India and Germany.

\section{The Euro-Mediterranean M odel of Breaks}

We must bear in mind that the passage from absolutist regimes to liberal regimes did not occur simultaneously in the different European states - and in some cases the gap in time could be as much as a century-, but the repercussions of 1789, year of the French Revolution, in some countries and the effect of imitation that it produced in others establishes it as the symbolic moment of the fall of Ancient Regimes and the beginning of printing freedom, in accordance with political history [9].

During the two World Wars, the European press merely defended the respective interests of the Allies and of the Germanophiles, turning the newspapers into strategic and propagandistic points of reference. As soon as each War ended, the States saw the need to intervene in the news sector. The victors learnt from the totalitarian experiences and from war that the media should fulfil a social function of public service, and thus the theory of media social responsibility was developed. From 1945 to 1970, there was a stage of economic expansion that had repercussions on the development of the news sector. States defended freedom of expression and, at the same time, established regulations of media control.

In Portugal the political power that took control after April 25, 1974 proceeded to nationalise the major daily newspapers, a situation that lasted until the 1980s when privatisation of the state-run newspapers took place. The National Salvation Junta Programme included the abolition of censorship and prior examination and defended the creation of a commission to control social communication, theatre and cinema until a new press law was enacted. This commission was to safeguard the emerging democracy from "reactionary" attacks and would have the authority to suspend organisms of social communication that threatened the principles put forward by the Junta [10].

The first major structural change that took place in the Portuguese press after April 25, 1974 was the total or partial transfer of a great number of the newspapers into the hands of the State as a consequence of the nationalisation of the banking sector and other basic sectors, due to their majority stake in the companies' capital as a result of credits previously granted to the newspaper businesses. The nationalisation of banking and insurance brought with it the 
Arts and Social Sciences Journal, Volume 2010: ASSJ-1

statization of the daily newspaper mastheads belonging to the most powerful economic groups. As pointed out by Mario Mesquita, oddly enough, nationalisation of the newspapers was never justified from a political viewpoint, but was always presented as an ind irect consequence of the banking sector [11].

The Press Law, published February 26, 1975, entered into effect at nearly the same time as the nationalisation of the banking sector, which brought about the indirect consequence of state control of the main mastheads. The approval of the Press Law of 1975 establishes freedom of expression, thought and print included in the right to information, as well as the right to create newspaper companies.

In Spain, from a regulatory point of view, democratic liberalisation of the press started in 1977 with the Decree-law. With the aim of preparing the June general elections, repealed or reformed the most restrictive articles of the law of 1966, especially 2 and 69 relating to limits on freedom of expression and of the right to information and the sanctions provided for in the case of its being violated. The Decree-law upheld, nonetheless, administrative seizure in any case of news against the unity of Spain, the M onarchy or the Armed Forces.

At the same time, the disappearance of the Franco regime's National M ovement (Movimiento Nacional) because of the Law of Political Reform of 1977, which launched the transition to democracy, made the transfer of their newspapers to an autonomous body of the Ministry of Information and Tourism compulsory. In addition, a Decree-law, some weeks before the 1977 elections, transferred the Movement's property to the State as part of its wealth, within an autonomous body of the State Social Communication Media. Shortly afterwards, the first democratic government (1977-79) abolished the M inistry of Information and Tourism, which opened the door to deregulation for the last time. Finally, the Constitution of 1978 revoked all the articles of the Law of 1966, which were against deregulation, specifically articles 20 and 38 relating to freedom of expression and of enterprise.

The liquidation of the publicly owned sector in its different aspects and the suppression of aid closed the cycle of regulation by the State that was typical in the Franco era. As a reaction to the previous intervention of the State and on the foundation of the 1978 Constitution, the new model left the development of the press strictly in private hands and with no State mediation, with only a few exceptions on the autonomous scale. With the specific laws repealed, as of 1989 only common legislation went on to regulate newspaper businesses, complemented by certain laws, for example, the right to reply or the conscience clause for journalists. On certain occasions, certain sectorial laws indirectly affect the press, such as, for example, the Law of Advertising and Institutional Communication, intended to regulate the central government's information, advertising and communication campaigns.

Although the opinion that the press should be subject to common law has prevailed, deregulatory policy has caused controversy with those in favour of considering the press a public service to be regulated the same way as the audiovisual media is. Insofar as the Constitutional Tribunal considers that the Administration must ensure the fulfilment of essential rights, news enterprises should have their own statute to safeguard them. How ever, the development of the law on aid to newspaper businesses of 1984 defined and regulated newspaper businesses and news agencies, but only in terms of receiving the aid stipulated. Therefore, aspects such as the form of these businesses, their composition, their shareholding transparency and their connections to other enterprises, and their internal regulations to guarantee freedom of expression are not regulated [2].

In Italy in 1948 the Legge sulla stampa was published. This regulated the Italian news publication system, which, with various modifications, has survived to the present. In this law, composed of 25 articles, the obligatory guidelines for print publications are defined: the civil responsibilities of the management in charge, registry, and punishment for defamation, etc. Thus, the Royal Decree of Law no.13 of January14, 1944 was abolished.

It was not until 1963, when article 29 of the La Legge sull'Ordine dei Giornalisti required the registration of journalists in a professional registry in order to work in the profession. Article 32 regulated an oral and written technical and practical

http://astonjournals.com/assj 
test of journalism as an essential requisite in order to obtain permission to work as a journalist. Article 33 also regulated the registry of practising professionals, establishing a minimum age of 18 and a declaration of the director of the Communications media (newspaper, radio, television or news agency) that certified the start of this professional practice; and later, after 18 months on the job, a declaration of the journalism activity carried out. In order to be registered, it was also necessary to have passed a general culture examination.

Article 45 of the Law of December 29, 1990 confirmed this registry, stating that no one could work as a journalist who was not registered in the professional registry (the law also specifies that citizens of member states of the European Community are equal to Italian citizens in terms of registration in the practising journalist registry, even though this condition of reciprocity had not been requested).

On the other hand, article 10 of the Law of August 5, 1981 indicated that registration in the national press registry was compulsory for editors of daily newspapers, magazines and news agencies. Moreover, although points of sale were regulated, no authorisation was necessary to sell them in party headquarters, churches, union headquarters...that had their own specialised publications.

On the other hand, the French state has been characterised by evident control of the system of press distribution and promotion, justifying it as a key element in the defence of pluralism in the news and in access to information. Within this framework, the circulation of the French press by the sale of individual copies, by which $70 \%$ of the copies are distributed, is subject to the principles in the Law of April 2, 1947, related to the status of newspaper and news publication distribution groups and businesses, established under the legal principle that there is no freedom of expression without freedom of circulation.

Regulation in the distribution system aims to guarantee each editor the possibility to access the chosen distribution system, whether it is a system based on the company's own resources or a group system. This is based on the principle that all editors should be equal in terms of the distribution system. There can be no discrimination in the public's access to the newspaper of their choice because of a publication's system of commercialisation. The State thus has the responsibility to correct certain market mechanisms in order to ensure the pluralism of the news.

In order to achieve its intentions, the Law of 47 organises distribution in view of the cooperative principle, establishing a messenger service system, guided by cooperatives of editors, so that circulation in the entire market is guaranteed to any masthead requesting it, eliminating barriers to new editors coming in.

However, beyond controlling the structure, what stands out is the way the state intervenes in the conditions of remuneration of all the parties involved in the distribution process, establishing it in accordance to percentages of the sum total of sales. Commissions are set by the legislator in order to ensure respect for the neutrality of circulation, considering it necessary to avoid discrimination in newspaper circulation and thus protecting the principle of equality and equal treatment among editors, set out in the Law of April 2, 1947. Decree no. 88-136 of February 9, 1988 sets the conditions for remunerations for newspaper sales agents, establishing that if the press depositories themselves operate points of sale, they cannot exceed $23 \%$ of total sales calculated on the sale price to the public. If they do not directly operate offices for sales to the public, they may obtain $24 \%$ in the case of newspapers and $29 \%$ for other periodical publications.

The vendors' commission (news kiosks, shops, etc.) may not exceed $15 \%$ of the total sales calculated on the sale price to the public, establishing exceptions such as Paris, where it can reach $18 \%$ in the case of the daily press. Said commissions may be improved by $5 \%$ in municipalities of more than 500,000 inhabitants. In the case of press sales agents, these commissions may be subject to an increase, as reflected in Decree no. 2005-1455 of November 25, 2005 that modifies Decree no. 88-136 of February 9, 1988.

http://astonjournals.com/assj 
This profit margin for the vendors, together with the management of between 1,000 and 3,000 products given them by the distributor, has sparked an alarming reduction in the number of news kiosks, down to 28,000 . Hence, in France there is one point of sale for every 2,000 inhabitants while in Spain it is one for every 1,400, or one for every 1,000 in Great Britain. Between 1995 and 2003, nearly 4,600 points of sale were lost in France.

The increase in unsold items, about $40 \%$, is another sign of the system's poor functioning. Measures to guarantee pluralism foment practices that cause the increase in returns, favouring editors' placement of copies in the news kiosks without adjusting supply to demand. This means that the press vendors, rather than being concerned with encouraging sales, work hard managing unsold copies.

In the face of this situation, the "Union Nationale de Diffuseurs de Presse (UNDP)" has proposed modifying the rules and authorising vendors to decide the number of different newspapers they can sell for themselves, depending on their clientele and the sales space they have, under the responsibility of the courier companies and newspaper depositories.

\section{Fiscal Control and Incentives in Press-State Relationships}

The fight against taxes and fees occupied the first half of the 19th century in Great Britain and took the form of a political clash between the popular, working class, progressive press and traditional powers using those methods to control it. Once the fiscal burden was overturned, the British press developed with no specific obstacles to business, following a liberal model.

Following the idea that information is a public service protected by the State, in the Euro-M editerranean countries aid policies have been applied to the press continually and, on many occasions, intensely, even in dictatorial periods. This aid has adopted many forms, from subsidies for paper to measures of intervention in the journalism profession, as in the case of Italy, or in distribution, as in France. The trend towards deregulation, especially in the case of Spain, has not completely done away with this aid, which European business associations have again protested.

\section{Great Britain: Fiscal Control}

At the beginning of the 19th century, British taxes on newspapers increased, which turned the English press into one of the most expensive in the world and its overall circulation was comparatively low. The progressive political currents and the incipient actions of the workers' movement (Utopian, Trade Unions, chartists, etc.), unable to pay the high taxes that the State required, began the Unstamped Movement and organised a newspaper without taxes in 1831. In 1802, for example, William Cobbet's "Political Register", an ingenious, independent political weekly that criticised any situation that did not favour man's freedom and independence began to be published.

The radical press (unstamped) was popular, progressive and working class and avoided state taxes through their own parallel distribution. This resistance held great importance, given that they achieved the first successes against taxes and in the long term were the cause of their disappearance. Furthermore, it was a key factor in the expansion of the chartist and union movement and of class consciousness as well as in the creation of the first popular press market, putting the working class masses in contact with periodical and serial publications. The government then launched an increased counteroffensive by raising punishments for those who read newspapers lacking the official post office stamp, promoting cheap press that was legal and, in the process, a "society" for popular instruction, collecting funds that allowed for the publication of the "Penny Magazine", and beginning to reduce the taxes in 1833 to start on the road to their abolition. This reaction by the government had favourable repercussions in normalising the English market, as by 1837 the radical press had either accepted the reduced taxes or had disappeared. 
The repeal of the public tax on newspapers between 1853 and 1861 caused an overall price reduction and an increase in circulation, founding what was known as the penny press or the mass press. As circulation increased, advertising grew, providing the editors with an important source of funding in addition to what came from sales. All these circumstances finally led to the generalised adoption of the halfpence newspaper in Great Britain in the 20th century.

While France and Italy began the Post War period in 1945 by following proposals in accordance with what is called the Welfare State, in the United Kingdom - and after the parenthesis of the Second World War- the press developed according to the liberal state model. Furthermore, and in opposition to the Euro-M editerranean countries where the role of the state is understood as a guarantee of pluralism, in the United Kingdom, freedom of the press is not constitutionally protected nor are the public freedoms of expression, in comparison to other countries [12]. In the U.K., the State regulates radio and television, but not the press and this is why only the BBC (begun in 1926) is understood to be a public service, not the press.

Differences in media regulation stand out. For instance, newspaper sales may be subject to the approval of the Monopolies and Mergers Commission, while sales of books is not. Moreover, until 1990, printed media was subject to the Obscene Publication Act, but the audiovisual media was not. The latter must be politically non-partisan, whereas traditionally it was presumed that newspapers were partisan [6]. It is also necessary to emphasise that in the United Kingdom political power was relatively concentrated in London [5], and that in the case of the popular press it is calculated that only $20 \%$ of income is from advertising versus that of quality press which receives nearly $60 \%$ of its income from advertising [5].

\section{State Incentives in the Euro-Mediterranean Model}

For newspaper editors aid to daily newspapers represent a strong regulatory tradition in most European countries with the exception of Spain. It was conceived of in order to defend and foment pluralism amidst the financial crisis of the seventies, and since then has been applied uninterruptedly in the majority of the countries [13]. In the case of the Portuguese press, what stands out is the implementation of the Porte pago or carriage payment, instituted on October 1,1976 . This consists of State participation in the issuing costs of periodical publications that rested on subscribers residing in national territory and abroad. The Carriage Payment was supported by the state's obligation to provide support, legally justified by the unfavourable socioeconomic environment [14].

At the end of the nineties, a stage of new incentives going into effect began which set off a conflict between those with a protectionist view of the State towards the 900 local and regional newspapers registered in the Institute of Social Communication (Instituto de Comunicação Social), and those defending a liberalisation process with new challenges in innovation and creativity, on which media survival must depend. Finally, in 2000 the end of the Carriage Payment was announced. The Secretary of State for Social Communication, Arons de Carvalho, showed his opposition to the former system that promotes passivity, opportunism and acceptance of subsidy dependence [cfr. www.secs.pt].

In 2001, the change was justified by the government in view of the need to modernise and professionalise the press sector. It was necessary to avoid the abusive use of the $100 \%$, tax that generated uncontrollable expenses and led to situations of unfair competition, and there was a need to provide incentives for the hiring of journalists. The progressive reduction of carriage payments is due to the perception of the measure as one that supports companies, not reading. The number of regional newspapers rose a great deal, reaching 900 while circulation decreased, which makes the effectiveness of that measure to support the promotion of newspaper reading doubtful.

Starting in January 2005 the State system of incentives to social communications began to be regulated by Decree-law no. $7 / 2005$, of January 6 . Its aim is to achieve objectives such as convert community social communication into a true agent for local and regional development, consistently widen the horizons of multimedia communication, promote the reading of local press as a real vehicle of culture, develop strategic agreements among communications organisations 
without affecting their commercial independence, and provide incentives for the hiring of communications professionals.

Once again, incentives for business initiative and multimedia development as specified in Decree law no. 7/2005, of January 6 , included in its objectives the development of regional and local newspaper and radio broadcasting companies, with the aim of professionalising their organisational structures and the qualifications of their personnel, and they were specifically directed at supporting strategic initiatives, infrastructure, technological and multimedia development and the promotion of the journalism product.

In 2007 incentives to business initiative, multimedia development and qualification were replaced with a sole incentive for local and regional social communications companies: incentives to the reading of regional press established in Decree-law no. 98/2007, of April 2. It is a regime of incentives to reading and sets a proportional distribution system for the postal cost of periodical publications, by which a process moderating the necessity for State intervention to transmit Portuguese culture and identity is carried out, considering the increase of new formats aimed at disseminating the news. State participation was set at $60 \%$ of mailing costs in 2007 , and has been reduced to $50 \%$ and $40 \%$, respectively, in 2008 and 2009.

Upon reduction of postal carriage costs, and within the press incentive plan, the creation of a regional press web portal was approved in the Council of Ministers (http://www.impressregional.com.pt/), and launched on April 5, 2007. The aim of this initiative is to permit electronic access to the content of regional periodical publications in Portugal and abroad. The Regional Press Portal, provided for in article 6 of Decree-law no. 98/2007, of April 2, is a result of the new regime of incentives to reading and access to information, and its objective is to stimulate technological innovation in the sector and expand the possibilities for access to Portuguese periodical publications anywhere in the world.

In the case of Spain, the governments of the Union of the Democratic Centre (Unión de Centro Democrático -UCD)" (1977-82) maintained a system of discretionally distributed aid to the press distributed discretionally which reached some 4 billion pesetas ( 25 million Euros). Although this aid carried much less weight than during the Franco period, the Socialist government still regulated a certain amount of aid to newspaper businesses and information agencies in 1984. The law distinguishes between two types of subsidies: direct subsidies to stimulate in particular the spread of the less sold general information newspapers, paper consumption and technological reconversion, and indirect subsidies in the areas of taxes, post, distribution and communication, in this case also for non-daily general interest publications. Between 1983 and 198714.2 billion pesetas (85 million Euros) in aid was awarded, supervised by the Congress of Deputies through annual reports.

Economic expansion, reflected in advertising, and the demands of the European Community ever since Spain entered, put an end to this aid. This was detrimental to small companies that required protectionist measures in order to survive. Direct aid was abolished by a law of 1988 , which partially repealed the law of 1984 . Some subsidies survived for linguistic reasons, however, in different regions of the State, awarded by the central government but limited to the autonomous communities having a co-official language. Indirect subsidies were mostly abolished in 1990. In any case, by 1991 all State aid had disappeared. Hence, today in Spain the only surviving aid is that relative to postage, which has minimal repercussions because companies have their own distributors. Additionally, only a 4\% VAT is applied to newspaper sales, but this also depends on community regulations. A renewal of direct aid to the press seems impossible, but indirect aid could be regained through fiscal reductions, especially that related to VAT, and corporate advertising [15], as well as that intended to promote reading and aid technology renewal [16].

In Italy the Law of August 5, 1981 stated in article 13 that State administrations and non-territorial public entities, excluding economic ones, should assign no less than a $70 \%$ share of the budgeted advertising expense to advertising in newspapers and magazines, with no discrimination and with equitable and objective criteria. Likewise, article 16 points

http://astonjournals.com/assj 
out that in order to reduce distribution costs and favour consortiums, regions may take support measures.

Although initially an inter-ministerial committee regulated the price, as of January 1, 1988 it became free. Decree 24 of April 2001 stated that the sale price set by the producer could not be modified at the point of sale. From 1981 to 1985, amounts ranking from 48 to 24 lira per copy were contributed to newspaper editors who issued between 50,000 and 200,000 copies. During this period, non-periodical publications and magazines also received aid in subsidies for the paper that was used, reaching up to 450 lira per kilogram (20 cents of a Euro). In this same period, press agencies were subsidised with up to four billion lira annually (two million Euros). In terms of telephone, telegram, postal and transport fees, a $50 \%$ reduction in telephone and telegram invoices, and of up to 50 billion lira annually (26 million Euros) for postal and telecommunications services stand out. Likewise financing was established for economic-production restructuring, including improvements to facilities, equipment, requalification of personnel, etc. This aid had a maximum duration of ten years. Law 7 of March 2001 continued the aid system, establishing a specific fund to strengthen the IT network, and the in-use connections of international telematic circuits and of satellites.

In the defence of reading and access to information, article 15 of the Law of 1981 states that all secondary schools and schools of higher education must have newspapers and magazines available for their students, as well as a place for them to be read. This right to information was extended in 1986, when aid was established for Italian publications published abroad and those published in Italy that were mainly issued abroad.

Likewise, publications of a "high cultural value" were subsidised. They had to have less than $50 \%$ advertising in addition to "highly scientific rigour". The maximum limit of funding could be no greater than $50 \%$ of its cost. In order to represent the country's linguistic pluralism, article 8 of 1987 states that contributions would increase by 15\% for those newspapers published in French, Ladino, Slovenian and German from the autonomous regions of the Aosta Valley, Friuli-Venezia Giulia and Trentino-Alto Adige.

Additionally, article 9 of the Law of 2001 established a fund to promote books and publications of great cultural value that would reach 2 billion lira annually (one million Euros).

Seeking protection in the freedom of dissemination of thought and equal access to information sources and the dissemination of this information, France promoted an aid system focussed on the dissemination and distribution of the press. This aid to the press is registered in State policy based on three main principles: aid to dissemination development, guarantees to publishing companies' independence and defence of their pluralism, and multimedia modernisation and diversification in newspaper businesses.

Yet upon analysing the press aid system, it is striking how a broad system of aid to the press to promote freedom of dissemination and access to sources is combined with a model of State control of newspaper businesses' activities. This is done in such a way that the distribution system and dissemination results referring to volume of copies are regulated by law, which undoubtedly has an effect on the strategies to be undertaken by press companies in order to compete.

In France, aid to the press is conceived of as aid to the reader, not as aid to companies. A good initiative for other countries to carry out is the one adopted by the French government that will subsidise free one-year newspaper subscriptions for young people between 18 and 24 years of age 2 .

In addition to promoting newspaper reading, this initiative hopes to achieve young customers' loyalty to a certain

\footnotetext{
${ }^{2}$ Since October 27, 2009, they can do this through the webpage www.monjournaloffert.fr. With a yearly budget of five million Euros, and three-year duration, this initiative hopes to offer 200,000 subscriptions. In this way, each read er will receive a weekly copy as a stratagem to socially develop reading habits, which are being transformed by the Internet.
} 
masthead determined independently of ideological, cultural and financial criteria.

Almost all direct aid is for publishing companies of newspapers and other political and general information publications. The other forms of press benefit only marginally. Framed within direct aid is aid to dissemination, aid to competition and maintenance of pluralism, and aid leading to modernisation and multimedia diversification of press companies.

Indirect aid benefits the press overall. The only condition is that the publication must respond to certain criteria before the Parity Commission for Publications and Press Agencies (CPPAP), such as a valid legal situation, regular publication, at least once ever trimester, use less than two thirds of its page surface for advertising and be subject to effective sales. This aid targets the postal system, with preferential fees, and the fiscal system.

Aid to distribution, as established in Decree no. 2004-1310 of November 26, 2004, is only for national political and general newspapers in French, published at least five times a week and beneficiaries of the registration certificate issued by the CPPAP. The aid is assigned based on the number of copies sold through normal channels.

The goal of aid for the distribution of national political and general interest press is to consolidate the cooperative press distribution system and to preserve the pluralism of political and general information press, and the necessary development for the effective exercise of freedom proclaimed in the Declaration of the Rights of Man and the Citizen 1789.

\section{Conclusions}

Unlike the Euro-M editerranean countries, where between 1926 and 1976 the different dictatorships modified not only the role of the press but also the relationship the State should have with it; in the United Kingdom's case, the existence of a perfectly consolidated and stable democracy favoured concern for and development of other forms of progress not only between the press and the State but between the press and all other economic and social players as well.

In the Euro-M editerranean countries, State intervention was intense in the second half of the 20th century. In France and Italy, this is due to the application of their own model of a welfare state. In Portugal and Spain methods of State control persisted well into the 80 s and profoundly affected the progress of their business systems.

In the cases of France and Italy, the end of the Second World War meant a major preoccupation with subjects such as prior censorship. Certainly, the reduction of freedoms, and specifically that of expression, has always been a central theme of those governing in times of democratic deficit.

It is as damaging for the development of a media system [17] to have interests in other fields of businesses (as in France and Italy), as is the ideological and political polarisation of opinions issued by the different media players (Spain).

Unlike the Euro-Mediterranean models analysed, the English-speaking press diversified its content internationally, rather than acquiring interests in other economic fields. These are large communications groups, but with influence only in the world of symbolic power.

Although at this time regulating the British press may seem necessary (distinguishing between quality press and popular press), it is practically impossible to change such an established tradition. From this perspective, State regulation regarding the limits to business concentration cannot be understood in solely ideological terms but rather in relation to news pluralism offered by different communications groups in press, radio and television. 
Development of the press today must integrate policies to renew technology, adapt to the market and benefit the readers. As in the case of France, regulation that defends the equality of all publishers in terms of the distribution system is important. Hence, the State has the responsibility to correct certain market mechanisms to guarantee information pluralism [18].

Once both models were analysed, we can affirm that there is no direct relationship between aid to the press and previous control of content by the State, but rather that it may be more significant if what is studied is the correspondence between indirect actions such as the awarding of institutional advertising, and pre-agenda factors[19]; understood to be those different positioning factors that previously limit, or determine in part, the content published by the communication media.

Compared to the Euro-M editerranean models, the British press has traditionally known how to adapt better to periods of crisis in the sector and lack of profits, for having always opted for industrial modernisation and knowing how to acquire a business focus instead of the other possible alternatives.

As a conclusion, we can point out that at this time it seems evident that the global press crisis not only has to do with the distinction between digital press and paper press, between balance of original content and agenda information, but also with the actions directed at promoting the reading of the daily press, overall among young people. In this regard, indepth study of the relations between Press and State is becoming increasingly pertinent.

If the British model requires company initiatives, and therefore, promotes the quality of newspapers, the EuroMediterranean model must understand its social function as aid directed at the reader and the defence of pluralism.

\section{References}

1. Saldaña MN, 2005. A Legacy of Supression (II): Del control de la información y opinión en la América colonial y prerrevolucionaria. La emergencia de la libertad de prensa. Derecho y Conocimiento, 3.

2. Gay C, 1991. La regulación del ejercicio de la profesión periodística. Revista de Administración Pública, 126: 385-408.

3. Albert P, 1970. L'Histoire de la Presse. París: Presses Universitaires de France.

4. Dérieux E, 2005. Droit des médias. Paris: Éditions Dalloz.

5. Spark C, 1999. The press. In The media in Britain. Edited by Stokes J. London: Macmillan Press.

6. Seymour-Ure C, 1996. The British Press and Broadcasting since 1945. Oxford: Blackwell Publishers.

7. Petley J, 1999. The Regulation of Media Content. In The Media in Britain: Current Debates and Developments. Macmillan: London.

8. Álvarez M , 1989. La prensa nacional británica. Un modelo para el análisis. Telos, 18.

9. Guillamet J, 2003. El periodismo en la transición del franquismo a la democracia. Factores políticos, económicos y profesionales. In Actas del V Congreso de Historiadores de la Comunicación. Palma de Mallorca: UIB, 269-274. 
10. Rui Cádima, F, 2002. A Comunicação Social em Portugal no Século XX - Fragmentos para a História de um Servidor de do is Amos. In Panorama da Cultura Portuguesa no século XX. Porto: Ed. Afrontamento Fundação Serralves.

11. M esquita M, 1996. Os medios de comunicação social. Portugal, 20 anos de democracia. In Temas e Debates. Lisboa.

12. Sarikakais K, 2004. British M edia in a Global Era. London: Arnold.

13. AEDE, 2008. Libro Blanco de la Prensa Diaria. [www.aede.es]

14. Aguado G, 2008. El mercado de la prensa portuguesa. Madrid: FIEC.

15. M orales A, 2006. Les ajudes a la premsa a Espanya. Ajuts a la premsa a Europa. Barcelona: ICOM/UAB.

16. Cambredó A, 2006. La visió i l'experiència de les empreses de premsa espanyoles. Ajuts a la premsa a Europa. Barcelona: ICOM/UAB.

17. Hallin D, Mancini P, 2008. Sistemas mediáticos comparados. Barcelona: Editorial Hacer (Comparing Media Systems. Cambridge University Press, 2004).

18. Aguado G, Sanmartí JM, Magallón R, 2009. The effect of the state on the evolution of print media. International Journal of Communication, $3 . \quad$ Available $\quad$ at [http://ijoc.org/ojs/index.php/ijoc/article/view/560]

19. Díaz B, 1995. La preagenda de los medios, expresión de la matriz mercantil de la comunicación. Tendencias. Madrid: Fundesco.

\section{Legislation}

Décret $n^{\circ} 2002-629$ du 25 avril 2002 instituant une aide à la distribution de la presse quotidienne nationale d'information politique et générale.

Décret n²004-1309 du 26 novembre 2004 modifiant le décret n` $99-79$ du 5 février 1999 modifié relatif au fonds d'aide à la modernisation de la presse quotidienne et assimilée d'information politique et générale et à la distribution de la presse quotidienne nationale d'information politique et générale.

Décret $n^{\circ} 2004-1310$ du 26 novembre 2004 modifiant le décret $n^{\circ} 2002-629$ du 25 avril 2002 instituant une aide à la distribution de la presse nationale d'information politique et générale.

Décret $n^{\circ}$ 2005-749 du 04 juillet 2005 modifiant le décret n $99-79$ du 5 février 1999 modifié relatif au fonds d'aide à la modernisation de la presse quotidienne et assimilée d'information politique et générale, et à la distribution de la presse quotidienne nationale d'information politique et générale.

Décret n²005-1455 du 25 novembre 2005 modifiant le décret n 88-136 du 9 février 1988.

Décret $n^{\circ} 2006-656$ du 2 juin 2006 modifiant le décret $n^{\circ} 99-79$ du 5 février 1999 modifié relatif au fonds d'aide à la modernisation de la presse quotidienne et assimilée d'information politique et générale et à la distribution de la presse 
quotidienne nationale d'information politique et générale.

Legge 2 febbraio 1939, n. 374. "Norme per la consegna obbligatoria di esemplari degli stampati e delle pubblicazioni”.

Legge 8 febbraio 1948, n. 47. "Disposizioni sulla stampa".

Legge 5 agosto 1981, n. 416 "Disciplina delle imprese editrici e provvidenze per l'editoria".

Legge 25 febbraio 1987, n. 67 - "Rinnovo della legge 5 agosto 1981, n. 416, recante disciplina delle imprese editrici e provvidenze per l'editoria".

Legge 7 marzo 2001, n. 62 "Nuove norme sull'editoria e sui prodotti editoriali e modifiche alla legge 5 agosto 1981, n.416".

Loi $n^{\circ}$ 47-585 du 2 avril 1947 relative au statut des entreprises de groupage et de distribution des journaux et publications periodiques.

Loi n. 86-897 du 1 août 1986_Portant Réforme du régime juridique de la presse. Journal Officiel, n. 54 du 2 aôut 1986, p. 9529-9530.

Loi n. 86-1067 du 30 septembre 1986 relative à la liberté de communication. Journal Officiel , núm. 32 , d'1 d'octubre de 1986, p. 11756-11759, 11763-11766.

Loi n 86-1210 du 27 novembre 1986 complétant la loi $n$ 86-897 du 1er août 1986 portant réforme du régime juridique de la presse.

http://astonjournals.com/assj 